\title{
Dark fermentation of xylose and glucose mix using isolated Thermoanaerobacterium thermosaccharolyticum W16
}

\author{
Nanqi Ren ${ }^{a, *}$, Guangli Cao ${ }^{a}$, Aijie Wang ${ }^{a}$, Duu-Jong Lee $^{a, b}$, \\ Wanqian $\mathrm{Guo}^{a}$, Yuhong $\mathrm{Zhu}^{a}$ \\ ${ }^{a}$ State Key Laboratory of Urban Water Resource and Environment, Harbin Institute of Technology, Harbin 150090, China \\ ${ }^{\mathrm{b}}$ Department of Chemical Engineering, National Taiwan University, Taipei, Taiwan
}

\section{A R T I C L E I N F O}

Article history:

Received 11 June 2008

Received in revised form

18 July 2008

Accepted 19 July 2008

Available online 18 September 2008

Keywords:

Thermoanaerobacterium

thermosaccharolyticum

Hydrogen production

Xylose

Fermentation

\begin{abstract}
A B S T R A C T
Hydrolyzed sugars from lignocellulosic biomass are primarily glucose and xylose. Efficient dark fermentation of isolated strains of both glucose and xylose to generate hydrogen is of considerable practical and academic importance. This study utilized a newly isolated, moderately thermophilic bacterium, W16, to produce hydrogen from xylose, glucose, and mixed xylose and glucose. The strain W16 was identified and designated as Thermoanaerobacterium thermosaccharolyticum W16. Physiology of strain W16 strain with numerous carbon sources and at $\mathrm{pH}$ of $4-7.5$ and temperature of $30-70{ }^{\circ} \mathrm{C}$ was demonstrated. The maximum cumulative $\mathrm{H}_{2}$ yield and $\mathrm{H}_{2}$ production rate obtained using the $\mathrm{W} 16$ strain in pure glucose and pure xylose tests were $2.42 \mathrm{~mol} \mathrm{H}_{2} \mathrm{~mol}^{-1}$ glucose and $12.9 \mathrm{mmol} \mathrm{H}_{2} \mathrm{~L}^{-1} \mathrm{~h}^{-1}$, and $2.19 \mathrm{~mol} \mathrm{H}_{2} \mathrm{~mol}^{-1}$ xylose and $10.7 \mathrm{mmol} \mathrm{H}_{2} \mathrm{~L}^{-1} \mathrm{~h}^{-1}$, respectively. The strain W16 also uptakes mixed xylose and glucose at comparable rates of individual pure sugar tests to produce biohydrogen via an acetate-butyrate-type fermentation. The isolated strain W16 was noted to effectively degrade reducing sugars in hydrolysate of corn stover collected in field.
\end{abstract}

๑ 2008 International Association for Hydrogen Energy. Published by Elsevier Ltd. All rights

reserved.

\section{Introduction}

Hydrogen is a promising alternative to fossil fuels as it is $\mathrm{CO}_{2}$ neutral, renewable and has a high energy yield. Lignocellulosic biomass, which primarily contains agricultural by-products and wood chips, is an ideal inexpensive, renewable and abundant resource for hydrogen [1]. Direct fermentation of raw lignocellulosic feedstock is typically inefficient. Hence, pre-treatments are commonly needed to saccharify lignocellulosic material into monomeric sugars, primarily glucose and xylose, prior to biological conversion. Glucose is easily biodegraded during hydrogen production by fermentation [2]. Conversely, fermentative hydrogen production from xylose is generally inefficient [3-8].

Hydrogen fermentation at high temperatures using thermophilic bacteria has garnered considerable attention due to the high hydrogen production rate, suppression of $\mathrm{H}_{2}$ consuming bacteria, and ability to utilize numerous substrates [9,10]. Particularly, hyper-thermophiles have higher hydrogen production potentials and yield fewer byproducts in dark fermentation compared with mesophiles $[7,11,12]$.

Glucose and xylose are the dominant reducing sugars when converting lignocellulosic biomass to hydrogen. Strains

\footnotetext{
* Corresponding author. Harbin Institute of Technology, School of Municipal and Environmental Engineering, No. 202 Haihe Road, 2nd Campus of HIT box 2614, Harbin, Hei Longjiang 150090, China. Tel./fax: +86 45186282008.

E-mail address: rnq@hit.edu.cn (N. Ren).

0360-3199/\$ - see front matter @ 2008 International Association for Hydrogen Energy. Published by Elsevier Ltd. All rights reserved. doi:10.1016/j.ijhydene.2008.07.107
} 
Table $1-\mathrm{H}_{2}$ yields and production rates reported in xylose fermentation studies

\begin{tabular}{|c|c|c|c|c|c|c|c|}
\hline Microorganism & Substrate & Culture mode & $\begin{array}{c}\text { Temperature } \\
\left({ }^{\circ} \mathrm{C}\right)\end{array}$ & $\mathrm{pH}$ & $\begin{array}{c}\text { HPR } \\
\left(\mathrm{mmol} \mathrm{L}^{-1} \mathrm{~h}^{-1}\right)\end{array}$ & $\begin{array}{c}\mathrm{H}_{2} \text { yield } \\
{\text { (mol } \mathrm{H}_{2} \mathrm{~mol}^{-1}}_{\text {substrate) }}\end{array}$ & Reference \\
\hline \multirow[t]{2}{*}{ Sewage sluge } & Xylose & Batch & 35 & $6-7$ & $5.94-8.93$ & $1.92-2.25$ & [13] \\
\hline & Xylose & Continuous & 35 & 7.1 & 4.15 & 0.7 & \\
\hline Sewage sludge & Xylose & Continuous & 40 & 6.5 & 25.4 & 0.8 & [8] \\
\hline Clostridium sp. No. 2 & Xylose & Continuous & 25 & 6.0 & 21.0 & 2.36 & [14] \\
\hline $\begin{array}{l}\text { Clostridium tyrobutyricum } \\
\text { ATCC } 25755\end{array}$ & Xylose & Batch & 37 & 6.3 & 8.35 & 0.77 & [4] \\
\hline Clostridium butyricum CGS5 & Xylose & Batch & 37 & 7.5 & 9.64 & 0.73 & [6] \\
\hline Enterobacter cloacae IIT-BT 08 & Xylose & Batch & 36 & 6.0 & 15.5 & 0.95 & [15] \\
\hline Microflora & Xylose & Batch & 75 & 7.3 & - & 0.54 & [5] \\
\hline Hydrogen-producing sludge & Xylose & Continuous & 50 & 7.0 & 5.76 & 1.4 & [7] \\
\hline Compost & Xylose & Fed-batch & 55 & 5.0 & 0.27 & 1.7 & [16] \\
\hline \multirow[t]{3}{*}{ C. saccharolyticus } & Xylose & Batch & 70 & 7.2 & 11.3 & 2.24 & [3] \\
\hline & Mix & Batch & 70 & 7.2 & 9.2 & 2.32 & \\
\hline & Glucose & Batch & 70 & 7.2 & 10.7 & 2.5 & \\
\hline \multirow[t]{3}{*}{ T. thermosaccharolyticum W16 } & Xylose & Batch & 60 & 6.5 & 10.7 & 2.19 & This study \\
\hline & Mix & Batch & 60 & 6.5 & $11.2-12.7$ & $2.23-2.37$ & \\
\hline & Glucose & Batch & 60 & 6.5 & 12.9 & 2.42 & \\
\hline
\end{tabular}

Marked are thermophilic tests.

that can effectively degrade glucose and xylose and a glucosexylose mix are of considerable academic and practical interest. However, according to summary in Table 1, a limited number of hyper-thermophiles that convert hydrogen from xylose and glucose have been identified and tested. This work isolates a hydrogen-producing strain that effectively converts xylose, glucose and a xylose-glucose mix into hydrogen via thermophilic fermentation. A particular strain, which was acquired from a hot spring, may generate high hydrogen yields from xylose, glucose or a xylose-glucose mix. Optimal solution temperature, $\mathrm{pH}$ and substrate concentrations to maximize $\mathrm{H}_{2}$ production from these sugars were identified. Moreover, the isolated strain was tested using a hydrolyzed solution obtained from corn stover feedstock collected in the field.

\section{Experiment}

\subsection{Strain isolation and identification}

Sludge sample was collected from a hot spring in Anshan, Liaoning Province, China. The temperature and $\mathrm{pH}$ of the hot spring were at $67{ }^{\circ} \mathrm{C}$ and 7.0 , respectively. In total, $1 \mathrm{~g}$ diluted (1:10) sludge sample was incubated at $60^{\circ} \mathrm{C}$ for $2 \mathrm{~h}$ in sterilized, modified MB medium [17], consisting of (per liter): $1.0 \mathrm{~g}$ $\mathrm{NH}_{4} \mathrm{Cl}, 0.3 \mathrm{~g} \mathrm{~K}_{2} \mathrm{HPO}_{4}, 0.3 \mathrm{~g} \mathrm{KH}_{2} \mathrm{PO}_{4}, 0.5 \mathrm{~g} \mathrm{MgCl} \cdot 6 \mathrm{H}_{2} \mathrm{O}, 2.0 \mathrm{~g}$ $\mathrm{NaCl}, 0.2 \mathrm{~g} \mathrm{KCl}, 0.05 \mathrm{~g} \mathrm{CaCl}_{2}, 0.5 \mathrm{~g}$ cysteine- $\mathrm{HCl}, 2.0 \mathrm{~g}$ yeast extract, $2.0 \mathrm{~g}$ tryptone, $10 \mathrm{~g}$ xylose, $1 \mathrm{~mL}$ trace element solution, $1 \mathrm{~mL}$ vitamin solution [18], and $1 \mathrm{ml} \mathrm{0.1 \% (w/v)} \mathrm{resazurin.}$ The $\mathrm{pH}$ of the oxygen-free medium was increased to 7.0 with $2 \mathrm{M} \mathrm{KOH}$, poured into the Hungate tubes and then autoclaved. Strain enrichment was achieved anaerobically in resting 100$\mathrm{mL}$ glass bottles containing $50 \mathrm{~mL}$ modified MB medium and $5 \mathrm{~mL}$ incubated sludge samples at $60^{\circ} \mathrm{C}$ for $5 \mathrm{~d}$. Suspensions acquired were plated on MB agar plates. Strain purification using the Hungate roll-tube procedure was repeated a few times until pure cultures were obtained at $60{ }^{\circ} \mathrm{C}$ in modified MB agar medium (2\%,w/v, agar) [19]. Capability to utilize $0.5 \%$ $\mathrm{v} / \mathrm{v}$ carbon substrates by isolates was observed in batch tests. Isolates with high hydrogen production potential from xylose (described later) were identified and tested.

Gram staining of isolate cells was performed following the Hucker method [20]. The morphology and motility of cells in their exponential-growth phase in MB medium were examined by light microscopy and electron microscopy.

The genomic DNA of selected isolates was extracted and purified using the bacterial DNA mini kit (Watson, Shanghai, China) according to manufacturer instructions. The $16 \mathrm{~S}$ rRNA was amplified by PCR using a pair of universal primers, 27F (5'AGAGTTTGATCCTGGCTCAG-3') and 1541R (5'-AAGGAGGTGATCCAGCC GCA-3'), which correspond to positions 8-27 and 1541-1525 [21]. The PCR products were purified using a UNIQ10 PCR product purification kit (Sangon, Shanghai, China) and cloned into vector pMD19-T using the pMD19-T vector system I kit according to manufacturer instructions (Takara, Dalian, China). The 16S rRNA sequence of the isolate was aligned

Table 2 - Hydrogen yields and metabolites from xylose with different strains

\begin{tabular}{|c|c|c|c|c|c|c|}
\hline \multirow[t]{2}{*}{ Strain } & \multirow{2}{*}{$\begin{array}{c}\mathrm{Y}_{\mathrm{H}_{2}} \\
\left(\mathrm{~mL} \mathrm{~L}^{-1}\right. \\
\text { culture) }\end{array}$} & \multirow{2}{*}{$\begin{array}{c}\mathrm{H}_{2} \\
\text { content } \\
(\%)\end{array}$} & \multicolumn{4}{|c|}{ Metabolities $\left(\mathrm{mgL}^{-1}\right)$} \\
\hline & & & Ethanol & Butanol & Acetate & Butyrate \\
\hline W16 & 2020 & 64 & 487 & 80.5 & 2050 & 1880 \\
\hline W4 & 1890 & 60 & 590 & ND & 1840 & 1980 \\
\hline W17 & 1870 & 59 & 636 & 97.4 & 1940 & 1790 \\
\hline D26 & 1540 & 53 & 1020 & 126 & 1680 & 1548 \\
\hline F3 & 1580 & 55 & 888 & 102 & 1510 & 1950 \\
\hline
\end{tabular}

ND: not detectable. 


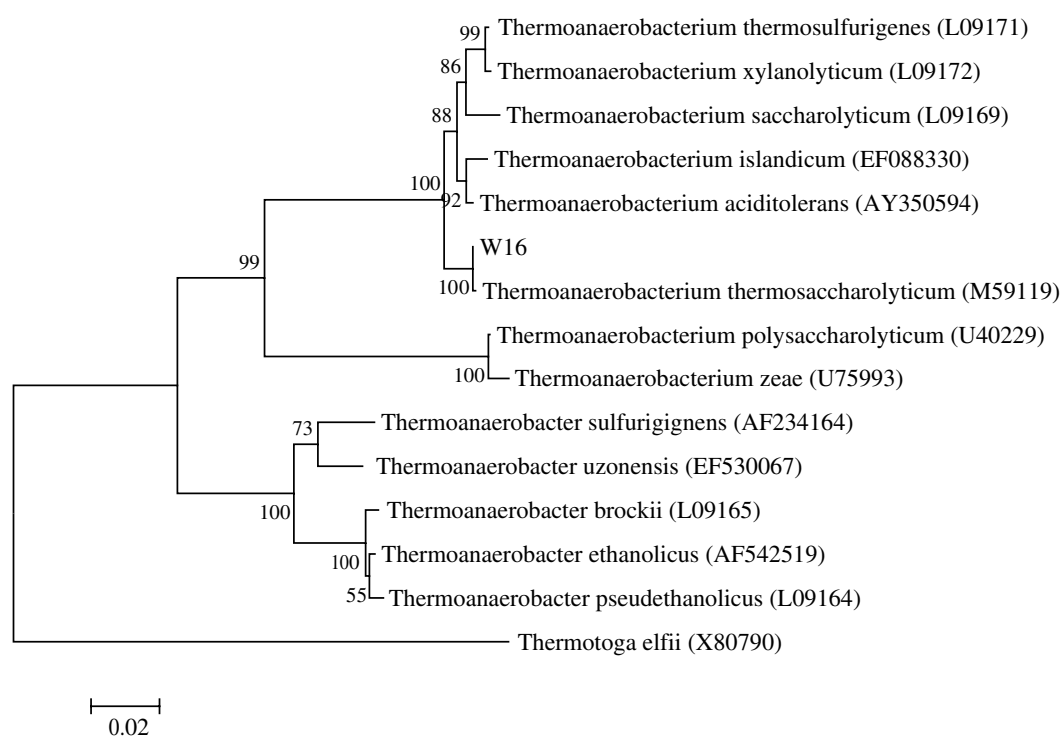

Fig. 1 - Phylogenetic tree showing the relationships between strain W16 and related species based on 16S rRNA gene sequences. The sequence of $T$. elifii served as an outgroup sequence. Bar represents $2 \%$ sequence divergence.

manually using the BLAST algorithm with all nucleotide sequences deposited in the GenBank database. Multiple alignments and calculation of degrees of sequence similarity were performed via Clustal $X$ [22]. The phylogenetic

Table 3 - Growth of T. thermosaccharolyticum strains reported in literature and in this work on carbon source utilization

\begin{tabular}{|c|c|c|c|c|}
\hline $\begin{array}{l}\text { Carbon } \\
\text { source }\end{array}$ & DSM571 [33] & FH1 [34] & PSU-2 [35] & $\begin{array}{c}\text { W16 } \\
\text { (This work) }\end{array}$ \\
\hline Sucrose & + & + & + & + \\
\hline Arabinose & + & + & + & + \\
\hline D-xylose & + & + & + & + \\
\hline Lactose & + & + & + & + \\
\hline Glucose & + & + & + & + \\
\hline Fructose & + & + & + & + \\
\hline Rhamnose & - & ND & + & + \\
\hline Mannose & + & ND & + & + \\
\hline Galactose & + & $\mathrm{N}$ & + & + \\
\hline Xylan & + & + & + & + \\
\hline Cellulose & ND & ND & + & + \\
\hline Cellubiose & + & + & + & + \\
\hline Dextrin & - & + & + & + \\
\hline Yeast extract & ND & + & + & + \\
\hline Peptone & ND & - & + & + \\
\hline Salicin & ND & ND & ND & + \\
\hline Maltose & + & + & + & + \\
\hline Mannose & + & + & + & + \\
\hline Hepatin & ND & + & ND & + \\
\hline Melizitose & ND & ND & ND & + \\
\hline Trehalose & + & ND & + & + \\
\hline Raffinose &,+- & + & + & + \\
\hline Starch & + & + & + & + \\
\hline Inulin & - & ND & ND & + \\
\hline Pectin & - & - & - & - \\
\hline Glycerol & - & - & - & - \\
\hline
\end{tabular}

relationship among isolates was constructed by the neighborjoining method [23] using MEGA 3.1 from the evolutionary distance data corrected by two-parameter model developed by Kumar et al. [24], and evaluated by bootstrap resampling [25] with 1000 replicates. The accession numbers of reference strains used in sequence comparisons were as follows: Thermoanaerobacterium thermosaccharolyticum (M59119), Thermoanaerobacterium aciditolerans (AY350594), Thermoanaerobacterium islandicum (EF088330), Thermoanaerobacterium thermosulfurigenes (L09171), Thermoanaerobacterium saccharolyticum (L09169), Thermoanaerobacterium xylanolyticum (L09172), Thermoanaerobacterium polysaccharolyticum (U40229), Thermoanaerobacterium zeae (U75993), Thermoanaerobacter sulfurigignens (AF234164), Thermoanaerobacter ethanolicus (AF542519), Thermoanaerobacter brockii (L09165), Thermoanaerobacter pseudethanolicus (L09164), Thermoanaerobacter uzonensis (EF530067) and Thermotoga elfii (X80790).

\subsection{Batch test of isolated strain with synthetic medium}

Individual isolates were cultivated anaerobically in a medium consisting of (per liter) $1.0 \mathrm{~g} \mathrm{NH}_{4} \mathrm{Cl}, 1.5 \mathrm{~g} \mathrm{~K}_{2} \mathrm{HPO}_{4}, 0.75 \mathrm{~g} \mathrm{KH}_{2} \mathrm{PO}_{4}$, $0.5 \mathrm{~g} \mathrm{MgCl}_{2} \cdot 6 \mathrm{H}_{2} \mathrm{O}, 2.0 \mathrm{~g} \mathrm{NaCl}, 0.2 \mathrm{~g} \mathrm{KCl}, 0.5 \mathrm{~g}$ cysteine- $\mathrm{HCl}, 2.0 \mathrm{~g}$ yeast extract, $2.0 \mathrm{~g}$ tryptone, and $10 \mathrm{~g}$ xylose. The inoculum acquired during the exponential-growth phase was added at $2 \% \mathrm{v} / \mathrm{v}$ with $50 \mathrm{~mL}$ medium in $100 \mathrm{~mL}$ glass serum bottles with $\mathrm{pH}$ adjusted to 7.0. In the subsequent tests, the effects of concentrations of different carbon substrates $\left(10 \mathrm{gL}^{-1}\right.$ for sucrose, arabinose, lactose, fructose, rhamnose, mannose, galactose, xylan, cellulose, cellubiose, dextrin, salicin, maltose, mannose, hepatin, melizitose, trehalose, raffinose, starch, inulin, pectin, or glycerol tests, and $0-25 \mathrm{~g} \mathrm{~L}^{-1}$ for xylose and glucose tests), yeast extract and tryptone $\left(0-5 \mathrm{~g} \mathrm{~L}^{-1}\right)$, solution $\mathrm{pH}(4-8)$ and temperature $\left(30-70^{\circ} \mathrm{C}\right)$ on hydrogen production potential were determined. In the test of the xylose-glucose 


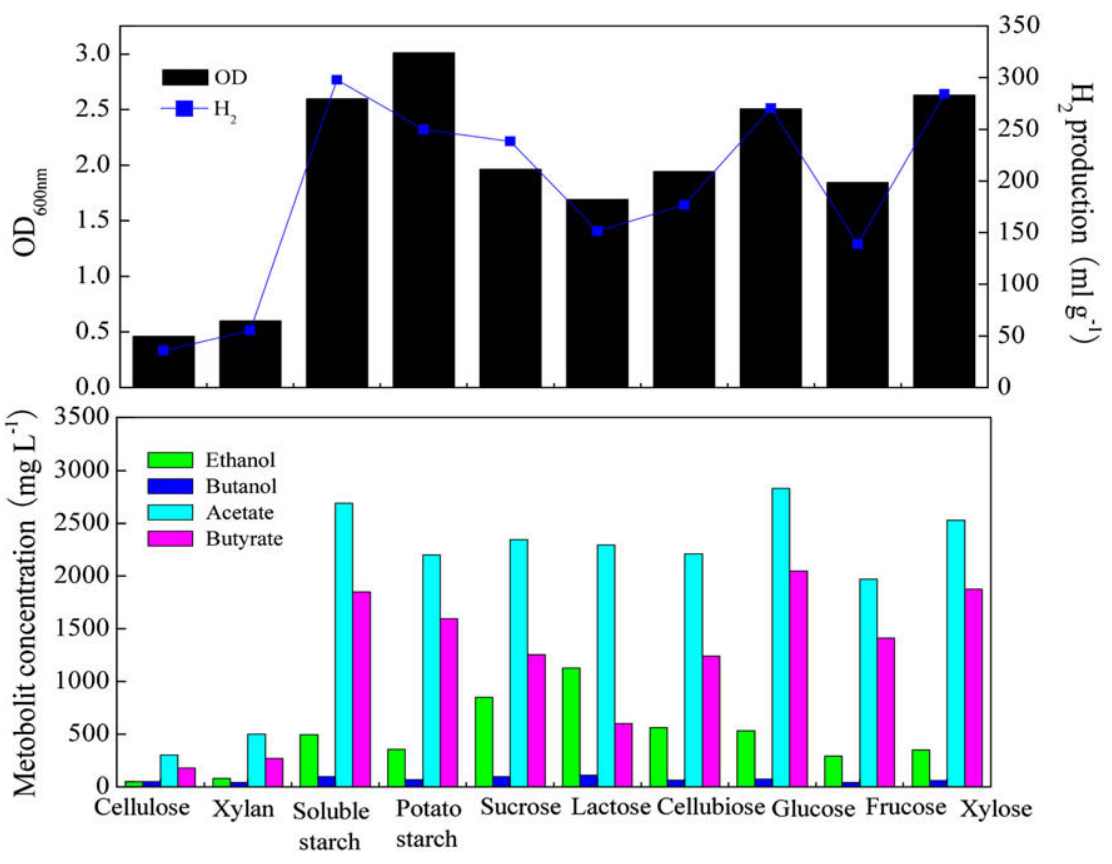

Fig. $2-\mathrm{H}_{2}$ production of T. thermosaccharolyticum W16 with different carbon sources at $10 \mathrm{~g} \mathrm{~L}^{-1}$ concentration, $60{ }^{\circ} \mathrm{C}$, initial pH 6.5. (A) Hydrogen production and cell density; (B) metabolites concentrations.

mix, total sugar concentration was maintained at $10 \mathrm{~g} \mathrm{~L}^{-1}$; the following mixture fractions were used: (xylose/glucose) $=100 /$ $0,80 / 20,50 / 50,20 / 80$, and 0/100. In batch tests, cell density, $\mathrm{pH}$, residual carbon substrate concentration, quantity and compositions of produced biogas, and metabolic products in liquid phase were determined.

\subsection{Batch test of isolated strain with hydrolysate of corn stover feedstock}

The corn stover feedstock containing $37.6 \% \mathrm{w} / \mathrm{w}$ cellulose, $21.5 \% \mathrm{w} / \mathrm{w}$ hemicellulose, $19.1 \% \mathrm{w} / \mathrm{w}$ lignin on the dry basis was collected at Harbin city, Heilongjiang Province, China. The hydrolysate of corn stover was prepared based on previously described procedures $[26,27]$. The corn stover chips $(2-10 \mathrm{~mm})$ were hydrolyzed at $121^{\circ} \mathrm{C}$ with $2.0 \%$ (w:v) sulfuric acid for $3 \mathrm{~h}$, with an initial liquid to solid ratio of 10:1. The resulting slurry $(5 \%, \mathrm{w} / \mathrm{v})$ was enzymatically hydrolyzed $\left(20 \mathrm{U} \mathrm{g}^{-1}\right.$ cellulose using cellulase from Sigma, $>0.3$ units $\mathrm{mg}^{-1}$ solid, derived from Aspergillus niger.) at $\mathrm{pH} 5.0,50^{\circ} \mathrm{C}, 200 \mathrm{rpm}$ for $72 \mathrm{~h}$. The $\mathrm{pH}$ of the hydrolysate, containing $17.3 \mathrm{gL}^{-1}$ of glucose, $12.6 \mathrm{gL}^{-1}$ of xylose and $1.9 \mathrm{gL}^{-1}$ arabinose, was adjusted to neutral with $\mathrm{NaOH}$. The neutralized hydrolysate was centrifuged and then diluted to yield a supernatant of reducing sugar concentrations of $5.8 \mathrm{~g} \mathrm{~L}^{-1}$ glucose, $4.2 \mathrm{~g} \mathrm{~L}^{-1}$ xylose and $0.6 \mathrm{~g} \mathrm{~L}^{-1}$ arabinose.

The inoculum acquired during the exponential-growth phase was also added at $2 \% \mathrm{v} / \mathrm{v}$ with $50 \mathrm{~mL}$ neutralized corn stover hydrolysate in $100 \mathrm{~mL}$ glass serum bottles with $\mathrm{pH}$ adjusted to 7.0. The tested hydrolysate was supplemented with the following nutrients (per litter) $\mathrm{NH}_{4} \mathrm{Cl} 1.0 \mathrm{~g}, \mathrm{~K}_{2} \mathrm{HPO}_{4}$ $1.5 \mathrm{~g}, \mathrm{KH}_{2} \mathrm{PO}_{4} 0.75 \mathrm{~g}, \mathrm{MgCl}_{2} \cdot 6 \mathrm{H}_{2} \mathrm{O} 0.5 \mathrm{~g}, \mathrm{NaCl} 2.0 \mathrm{~g}, \mathrm{KCl} 0.2 \mathrm{~g}$,

\begin{tabular}{|c|c|c|c|c|c|c|c|}
\hline \multicolumn{4}{|c|}{ Medium components $\left(\mathrm{g} \mathrm{L}^{-1}\right)$} & Consumed $\left(\mathrm{m} \mathrm{mol} \mathrm{L}^{-1}\right)$ & \multicolumn{3}{|c|}{ Produced (m mol L ${ }^{-1}$ medium) } \\
\hline Xylose & Yeast extract & Tryptone & $\mathrm{OD}_{600 \mathrm{~nm}}$ & Xylose & Hydrogen & Acetate & Butyrate \\
\hline 0 & 5 & 2 & 0.15 & - & 3.2 & 3.4 & 0.5 \\
\hline 0 & 5 & 5 & 0.15 & - & 3.2 & 3.3 & 0.6 \\
\hline 0 & 2 & 0 & 0.06 & - & 2.0 & 1.7 & 0.4 \\
\hline 0 & 2 & 2 & 0.10 & - & 2.4 & 2.2 & 0.5 \\
\hline 5 & 5 & 2 & 1.85 & 33.3 & 64.3 & 16.1 & 8.5 \\
\hline 5 & 5 & 5 & 2.05 & 33.3 & 57.9 & 13.8 & 10.0 \\
\hline 5 & 2 & 0 & 1.33 & 30.5 & 45.8 & 11.5 & 5.2 \\
\hline 5 & 2 & 2 & 1.71 & 31.7 & 47.4 & 12.8 & 7.3 \\
\hline 5 & 0 & 0 & 0.73 & 29.5 & 40.2 & 11.3 & 4.2 \\
\hline
\end{tabular}



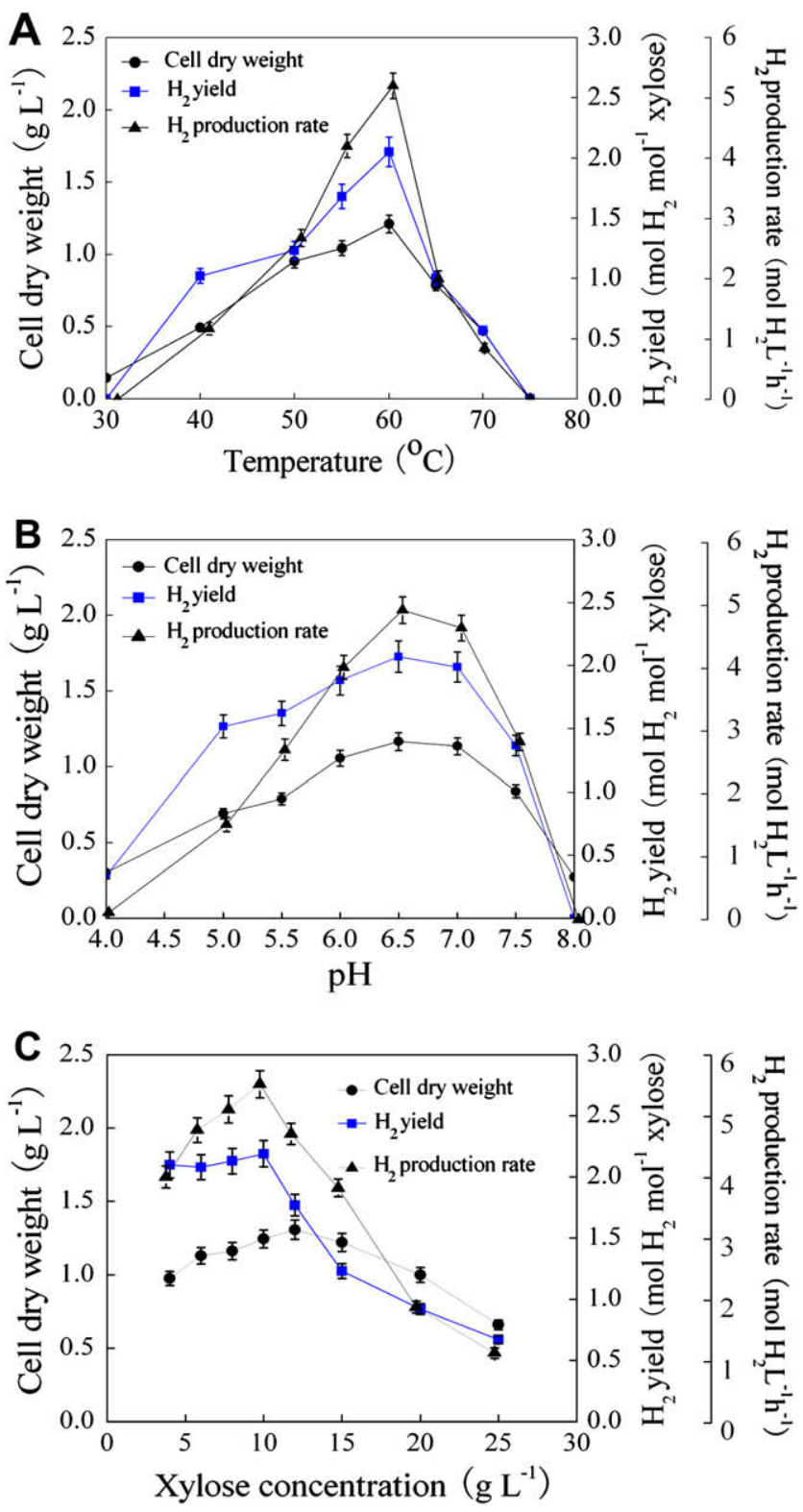

Fig. 3 - Effect of process parameters on hydrogen production using strain W16. 25-h batch test. (A) Effects of temperature, initial $\mathrm{pH} 6.5$, xylose concentration $10 \mathrm{~g} \mathrm{~L}^{-1}$. (B) Effects of initial $\mathrm{pH}, 60^{\circ} \mathrm{C}$, xylose concentration $10 \mathrm{~g} \mathrm{~L}^{-1}$. (C) Effects of xylose concentration, $60^{\circ} \mathrm{C}$, initial pH 6.5 .

cysteine- $\mathrm{HCl} 0.5 \mathrm{~g}$, yeast extract $2.0 \mathrm{~g}$, and tryptone $2.0 \mathrm{~g}$. In a parallel test synthetic medium with the same levels of principal reducing sugars $\left(5.8 \mathrm{gL}^{-1}\right.$ glucose, $4.2 \mathrm{gL}^{-1}$ xylose and $0.6 \mathrm{gL}^{-1}$ arabinose) and of other micronutrients was tested with the isolated strain.

\subsection{Analytical methods}

Cell density in the liquid medium was monitored by measuring turbidity at $600 \mathrm{~nm}$. The xylose, arabinose and glucose concentrations in filtered samples were measured using high- performance liquid chromatography (HPLC) (Thermo Electron Corporation, Boston, MA, USA). Volatile fatty acids and alcohols were detected by gas chromatography (GC-SC2) (Shanghai Analytical Apparatus, Shanghai, China) equipped with a hydrogen flame-ionization detector and a 2.0-m stainlesssteel column packed with GDX103 (60/80 mesh). Gases were measured by GC-SC2 equipped with a thermal conductivity detector and a 2.0-m stainless-steel column packed with TDS$01(60 / 80 \mathrm{mesh})$ and $\mathrm{N}_{2}$ at a flow rate of $70 \mathrm{~mL} \mathrm{~min}^{-1}$ as the carrier gas. Hydrogen yield $\left(\mathrm{Y}_{\mathrm{H}_{2}}\right)$ was calculated as $\mathrm{Y}_{\mathrm{H}_{2}}=$ (accumulated biogas production quantity) $\times$ (hydrogen content in gas)/(consumed sugarunder quantity). In the glucose-xylose mix culture, hydrogen yield was calculated as $\mathrm{Y}_{\mathrm{H}_{2}}=$ (accumulated biogas production quantity) $\times$ (hydrogen content in gas)/(consumed glucose quantity + consumed xylose quantity).

\section{Experimental results}

\subsection{Strain screening}

Isolated strains were tested for hydrogen production potential using the medium described in Section 2.2 at $60^{\circ} \mathrm{C}$. Five strains, W16, W4, W17, D26 and F3, had high hydrogen yields from xylose with acetate, butyrate and ethanol as the principal metabolites (Table 2). Strain W16 had higher hydrogen yield (2020 $\mathrm{mL} \mathrm{L}^{-1}$ culture) that the other four strains (1540$1890 \mathrm{~mL} \mathrm{~L}^{-1}$ culture). Hence, strain W16 was examined further.

\subsection{Identification and characterization of strain W16}

Morphological and physiological tests demonstrate that strain W16 was rod-shaped, Gram-positive, strictly anaerobic, and spore-forming (data not shown for brevity). Cells were motile, as observed under light microscopy, and flagella were observed.

The complete 16S rRNA gene sequence (1509 bp) of the W16 strain was deposited at GenBank and EMBL (accession number, EU563362). Based on the similarity analysis of the $16 \mathrm{~S}$ rRNA gene, a phylogenetic tree for the W16 strain rooted with T. elfii was constructed (Fig. 1); the closest relationship of the gene was with $\mathrm{T}$. thermosaccharolyticum DSM571 (formerly Clostridium thermosaccharolyticum) at a similarity of $98.4 \%$. The phenotypical characteristics of the W16 isolate were also consistent with $\mathrm{T}$. thermosaccharolyticum; thus, the isolated strain was characterized as $\mathrm{T}$. thermosaccharolyticum and designated as T. thermosaccharolyticum W16.

The strain $T$. thermosaccharolyticum is a thermophilic saccharolytic microorganism that effectively produces hydrogen from acetate/butyrate fermentation of carbohydrates (but not xylose) $[10,28,29]$. This strain was examined in a thermophilic, anaerobic sequencing batch reactor [30], trickling biofilter reactors [31] and continually stirred tank reactors [29,32]. The W16 strain and other $\mathrm{T}$. thermosaccharolyticum strains reported in literature can grow on a wide variety of complex and simple carbohydrates (Table 3). However, no study has demonstrated that $\mathrm{T}$. thermosaccharolyticum can utilize xylose to generate hydrogen. 


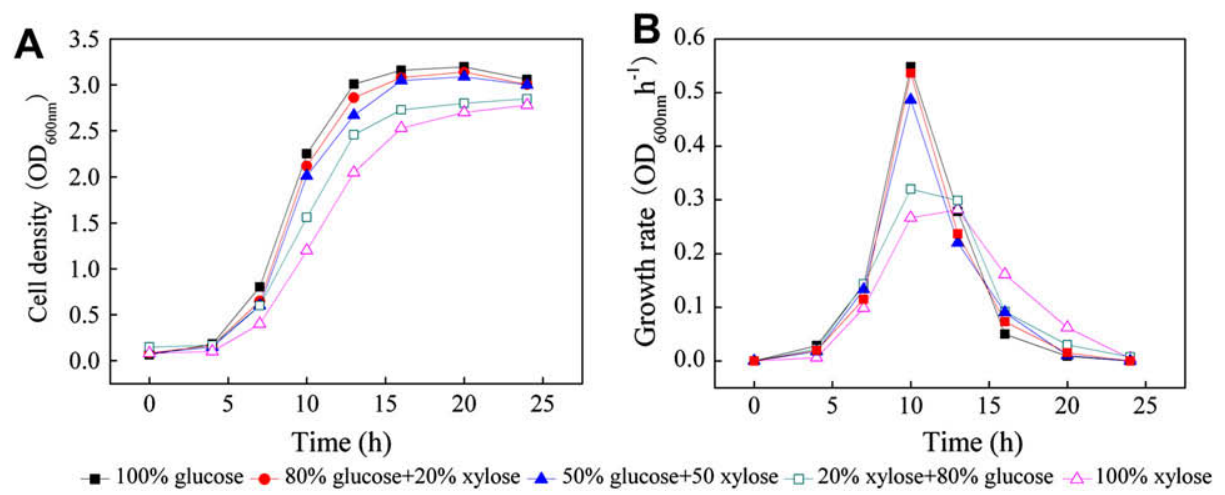

Fig. 4 - Growth of strain W16 on glucose, xylose and their mix. Initial total sugar concentration $=10 \mathrm{~g} \mathrm{~L}^{-1}$. $2 \% \mathrm{v} / \mathrm{v}^{\mathrm{inoculum}}$.

\subsection{Effects of process parameters on hydrogen production via strain W16}

\subsubsection{Effects of carbon sources}

At $60^{\circ} \mathrm{C}$, strain W16 effectively utilizes starch (soluble starch and potato starch), disaccharides (cellobiose, lactose and sucrose) and monosaccharides (glucose, fructose and xylose) to generate hydrogen (Fig. 2). A strong correlation existed between hydrogen production quantity and cell density $\left(\mathrm{OD}_{600 \mathrm{~nm}}\right)$. The predominant metabolites are acetate, butyrate, and ethanol. Degradation of cellulose and xylan was poor using strain W16.

Table 4 lists hydrogen yield, xylose consumption rate, and metabolite concentrations for W16 at different xylose, yeast extract and tryptone loadings. With no added xylose, production of hydrogen and other liquid metabolites by W16 was limited (2.0-3.2 $\left.\mathrm{mmol} \mathrm{H}_{2} \mathrm{~L}^{-1}\right)$. Corresponding cell growth was restricted $\left(\mathrm{OD}_{600 \mathrm{~nm}}=0.06-0.15\right)$. Hence, with yeast extract concentration up to $5 \mathrm{~g} \mathrm{~L}^{-1}$, hydrogen production by W16 was not affected significantly. Conversely, the W16 strain degraded effectively xylose without yeast extract or tryptone $\left(40.2 \mathrm{mmol} \mathrm{H}_{2} \mathrm{~L}^{-1}\right)$. However, with $5 \mathrm{~g} \mathrm{~L}^{-1}$ yeast extract and $2 \mathrm{gL}^{-1}$ tryptone, the W16 strain increased its hydrogen production ( $64.3 \mathrm{mmol} \mathrm{H}_{2} \mathrm{~L}^{-1}$ ); additionally, corresponding cell growth also increased $\left(\mathrm{OD}_{600 \mathrm{~nm}}=1.85\right)$.

\subsubsection{Effect of solution temperature, $p H$, and initial xylose} concentration

Hydrogen yield, hydrogen production rate, and cell mass were functions of solution temperature, $\mathrm{pH}$, and xylose concentration following $25 \mathrm{~h}$ batch fermentation (Fig. 3). Fermentation tests were performed using the same medium as described in Section 2.2. Concentrations of all components except for xylose were fixed in all experiments.

Generally, hydrogen yield, hydrogen production rate, and cell mass increased first, then decreased after exceeding a maximum when increasing solution temperature, $\mathrm{pH}$ or initial xylose concentration. Particularly, using the test conditions in Fig. 3 as an example, maximum hydrogen yield (2.0-2.2 $\mathrm{mol} \mathrm{H}_{2} \mathrm{~mol}^{-1}$ xylose), hydrogen production rate (5.0$5.5 \mathrm{mmol} \mathrm{H}_{2} \mathrm{~L}^{-1} \mathrm{~h}^{-1}$ ), and cell mass (1.1-1.3 $\mathrm{g} \mathrm{L}^{-1}$ ) occurred at $60{ }^{\circ} \mathrm{C}$, pH of 6.5 and $10-12.5 \mathrm{~g} \mathrm{~L}^{-1}$ xylose. Additionally, the W16 strain degraded xylose with a satisfactory efficiency at 55-
$60{ }^{\circ} \mathrm{C}$, pH of 5.5-7.0, and xylose concentration $<15 \mathrm{gL}^{-1}$. This observation demonstrates the importance of properly controlling reaction temperature and solution $\mathrm{pH}$ to achieve high activity of the W16 strain. Moreover, reduction of W16 activity at high xylose concentration may be yielded by $\mathrm{pH}$ change or product inhibition. Continuous flow reactor can easily remove this restriction in practice.

\subsection{Production of hydrogen from xylose/glucose mix}

The W16 strain can grow on glucose, xylose, and a glucosexylose mix (Fig. 4); the strain prefers glucose over xylose. With a fixed total sugar quantity $\left(10 \mathrm{~g} \mathrm{~L}^{-1}\right)$, the $\log$ phase growth of strain W16 was 4-13 h for the pure glucose test and 6-16 h for the pure xylose test.

Table 5 lists the experimental results for batch fermentation of the xylose/glucose mix using strain W16. The presence of $80 \%$ xylose reduced the utilization rate of glucose slightly from around $0.36 \mathrm{~g} \mathrm{~L}^{-1} \mathrm{~h}^{-1}$ to $0.25 \mathrm{~g} \mathrm{~L}^{-1} \mathrm{~h}^{-1}$. Conversely, the presence of $50 \%$ glucose markedly reduced the utilization rate of xylose from around $0.29 \mathrm{gL}^{-1} \mathrm{~h}^{-1}$ to $0.09 \mathrm{gL}^{-1} \mathrm{~h}^{-1}$. Hence, the content of glucose in the mixture had great effect on the consumption of xylose, however, the glucose consumption rate remained essentially constant independent of the xylose content. The cumulative hydrogen yield per mole substrate of glucose and xylose was $2.42 \mathrm{~mol}$ hydrogen and $2.19 \mathrm{~mol}$ hydrogen corresponding to $13.57 \mathrm{mmol} \mathrm{H}_{2} \mathrm{~g}^{-1}$ glucose and $14.40 \mathrm{mmol} \mathrm{H}_{2} \mathrm{~g}^{-1}$ xylose, respectively. Apparently, strain W16 exhibited efficient degradation of xylose for hydrogen production as glucose. The final yield of hydrogen in the mixture was not distinctively different from the pure sugar medium. In other words, strain W16 could utilize the xyloseglucose mix for hydrogen production from hydrolyzed lignocellulose.

\subsection{Production of hydrogen from corn stover hydrolysate}

The strain $\mathrm{T}$. thermosaccharolyticum W16 degraded completely the arabinose and glucose and $>55 \%$ xylose in the corn stover hydrolysate to hydrogen, acetate, butyrate, and ethanol (Fig. 5). The tests with synthetic medium of the same reducing sugar levels also revealed a similar result. Specifically, the 


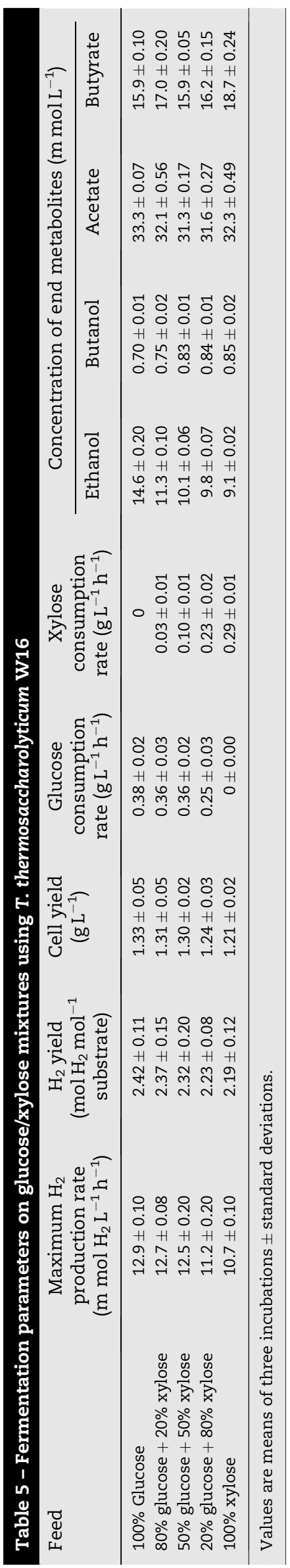

strain W16 produced biohydrogen from corn stover hydrolysate and synthetic medium at 2.3-2.4 $\mathrm{mol} \mathrm{H}_{2} \mathrm{~mol}^{-1}$ substrate and at $12.0-12.7 \mathrm{~mol} \mathrm{H}_{2} \mathrm{~L}^{-1} \mathrm{~h}^{-1}$ production rates. Apparently, the components in hydrolysate of corn stover did not inhibit the growth of strain W16. Additionally, the strain W16 produced equally well the biohydrogen from corn stover hydrolysate than that from mix of pure glucose and xylose (2.2-2.4 $\mathrm{mol} \mathrm{H}_{2} \mathrm{~mol}^{-1}$ xylose).

\section{Discussion}

Table 1 compares $\mathrm{H}_{2}$ yields and production rates reported in xylose fermentation studies. Thermophiles typically generate higher hydrogen yield from xylose $\left(1.7-2.5 \mathrm{~mol} \mathrm{H}_{2} \mathrm{~mol}^{-1}\right.$ xylose) than mesophiles (commonly $<1 \mathrm{~mol} \mathrm{H}_{2} \mathrm{~mol}^{-1}$ xylose). Conversely, with a novel reactor design and cell immobilization technology, the hydrogen production rate from xylose can achieve a high level [8]. Hence, optimizing reactor design should enhance the hydrogen production rate for thermophiles from xylose. Among the thermophiles tested in literature (Table 1), strain W16 and the strain Caldicellulosiruptor saccharolyticus [3] obtained peak hydrogen yields and hydrogen production rates from xylose and glucose which are the primary hydrolyzed product from lignocellulose. The hydrogen yield and hydrogen production rate of $T$. thermosaccharolyticum W16 were not distinct from synthetic medium, it showed that the strain could tolerance the inhibit component existed in the hydrolysate. However, the hydrogen production rate of the $C$. saccharolyticus reduced on the hydrolysate [3] indicated the strain was influenced by the components in the hydrolysate. From the point of industrial application, the stains possessed the tolerance of inhibitors is advantageous.

\section{Conclusions}

This study investigates the use of a newly isolated, moderately thermophilic bacterium, W16, to produce hydrogen from xylose, glucose, and mixed xylose and glucose. The bacterium was isolated at a hot spring in northern China, identified based on 16S rRNA gene sequences as T. thermosaccharolyticum and designated herein as T. thermosaccharolyticum W16. The W16 strain uses numerous carbon sources for $\mathrm{H}_{2}$ production at a $\mathrm{pH}$ of $4-7.5$ and temperature of $30-70^{\circ} \mathrm{C}$. The optimal $\mathrm{pH}$ and temperature for hydrogen production are 6.5 and $60^{\circ} \mathrm{C}$, respectively, with xylose and starch as the preferred substrates. The yeast extract and tryptone are not prerequisites for the growth of strain W16, but they aid the growth of W16. The maximum cumulative $\mathrm{H}_{2}$ yield and $\mathrm{H}_{2}$ production rate obtained using the $\mathrm{W} 16$ strain in pure glucose and pure xylose tests were $2.42 \mathrm{~mol} \mathrm{H}_{2} \mathrm{~mol}^{-1}$ glucose and $12.9 \mathrm{mmol} \mathrm{H}_{2} \mathrm{~L}^{-1} \mathrm{~h}^{-1}$, and $2.19 \mathrm{~mol} \mathrm{H}_{2} \mathrm{~mol}^{-1}$ xylose and $10.7 \mathrm{mmol} \mathrm{H}_{2} \mathrm{~L}^{-1} \mathrm{~h}^{-1}$, respectively. In the mixed sugar tests, W16 uptakes both xylose and glucose, but prefers glucose over xylose as the substrate. The hydrogen production rate and hydrogen yield for the mixed sugar tests decreased from $12.7 \mathrm{mmol} \mathrm{H}_{2} \mathrm{~L}^{-1} \mathrm{~h}^{-1}$ and $2.37 \mathrm{~mol} \mathrm{H}_{2} \mathrm{~mol}^{-1}$ substrate to 11.2 $\mathrm{mmol} \mathrm{H}_{2} \mathrm{~L}^{-1} \mathrm{~h}^{-1}$ and $2.23 \mathrm{~mol} \mathrm{H}_{2} \mathrm{~mol}^{-1}$ substrate as the 

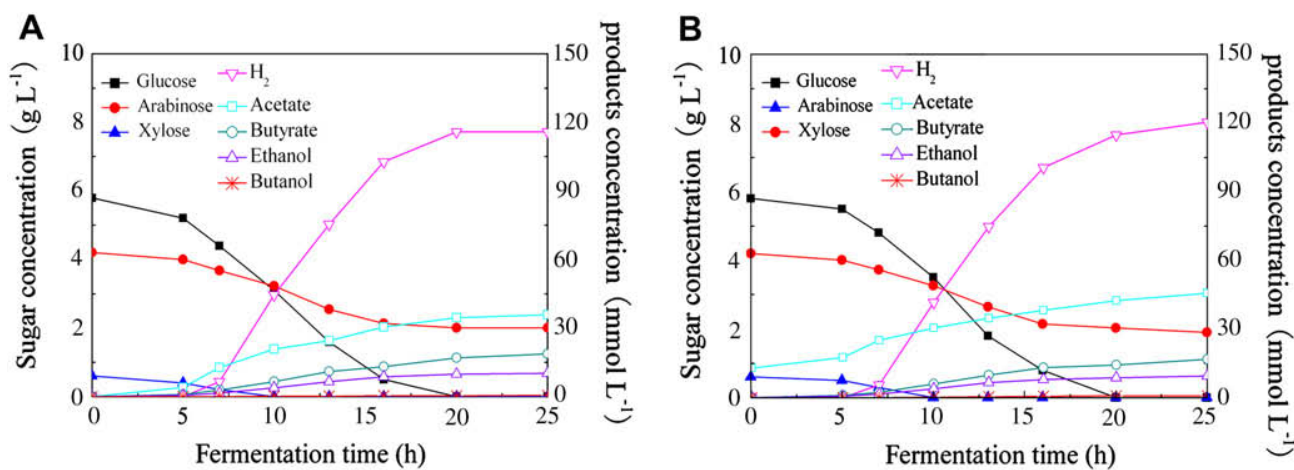

Fig. 5 - Hydrogen production by T. thermosaccharolyticum W16 using (A) corn stover hydrolysate and (B) synthetic medium having the same sugar concentrations as in the corn stover hydrolysate with inoculum $2 \%(\mathrm{v} / \mathrm{v})$, initial $\mathrm{pH} 6.5$.

xylose fraction increased. The end products were predominantly acetate and butyrate, which generated an acetatebutyrate-type fermentation. The isolated strain degrades as efficient the reducing sugars in hydrolysate of corn stover feedstock as the xylose/glucose mix.

\section{Acknowledgement}

This research was supported by National Natural Science Foundation of China (50678049).

\section{R E F E R E N C E S}

[1] Chandakant P, Bisaria VS. Simultaneous bioconversion of cellulose and hemicellulose to ethanol. Crit Rev Biotechnol 1998;18:295-331.

[2] Fang HHP, Liu H. Effect of $\mathrm{pH}$ on hydrogen production from glucose by a mixed culture. Bioresour Technol 2002;82:87-93.

[3] Kadar Z, Vrije TD, van Noorden GE, Budde MAW, Szengyel Z, Reczey K, et al. Yields from glucose, xylose, and paper sludge hydrolysate during hydrogen production by the extreme thermophile Caldicellulosiruptor saccharolyticus. Appl Biochem Biotechnol 2004;113-116:497-508.

[4] Zhu Y, Yang ST. Effect of pH on metabolic pathway shift in fermentation of xylose by Clostridium tyrobutyricum. J Biotechnol 2004;110:143-57.

[5] Yokoyama H, Moriya N, Ohmori H, Waki M, Ogino A, Tanaka Y. Community analysis of hydrogen-producing extreme thermophilic anaerobic microflora enriched from cow manure with five substrates. Appl Microbiol Biotechnol 2007;77(1):213-22.

[6] Lo YC, Chen WM, Hung CH, Chen SD, Chang JS. Dark $\mathrm{H}_{2}$ fermentation from sucrose and xylose using $\mathrm{H}_{2}$-producing indigenous bacteria: feasibility and kinetic studies. Water Res 2008;42:827-42.

[7] Lin CY, Wu CC, Hung CH. Temperature effects on fermentative hydrogen production from xylose using mixed anaerobic cultures. Int J Hydrogen Energy 2008;33:43-50.

[8] Wu SY, Lin CY, Lee KS, Hung CH, Chang JS, Lin PJ, et al. Dark fermentative hydrogen production from xylose in different bioreactors using sewage sludge microflora. Energy Fuels 2008;22:113-9.
[9] Talabardon M, Schwitzguebel JP, Peringer P. Anaerobic thermophilic fermentation for acetic acid production from milk permeate. J Biotechnol 2000;76:83-92.

[10] Fang HHP, Zhang T, Liu H. Biohydrogen production from starch in wastewater under thermophilic condition. J Environ Manage 2003;69:149-56.

[11] van Niel EWJ, Budde MAW, de Haas GG, van der Walb FJ, Claassenb PAM, Stamsa AJM. Distinctive properties of high hydrogen producing extreme thermophiles Caldicellulosiruptor saccharolyticus and Thermotoga elfii. Int J Hydrogen Energy 2002;27:1391-8.

[12] van Niel EWJ, Claassenb PAM, Stamsa AJM. Substrate and product inhibition of hydrogen production by the extreme thermophile, Caldicellulosiruptor saccharolyticus. Biotechnol Bioeng 2003;81:255-62.

[13] Lin CY, Cheng CH. Fermentative hydrogen production from xylose using anaerobic mixed microflora. Int J Hydrogen Energy 2006;31:832-40.

[14] Taguchi F, Mizukami N, Saito-Taki T, Hasegawa K. Hydrogen production from continuous fermentation of xylose during growth of Clostridium sp. strain No. 2. Can J Microbiol 1995;41: 536-40.

[15] Kumar N, Das D. Enhancement of hydrogen production by Enterobacter cloacae IIT-BT 08. Process Biochem 2000;35:589-93.

[16] Calli B, Schoenmaekers K, Vanbroekhoven K, Diels L. Dark fermentative $\mathrm{H}_{2}$ production from xylose and lactose-effects of on-line pH control. Int J Hydrogen Energy 2008;33:522-30.

[17] Fardeau ML, Ollivier B, Patel BKC, Magot M, Thomas P, Rimbault A, et al. Thermotoga hypogea sp. nov., a xylanolytic, thermophilic bacterium from an oil-producing well. Int J Syst Bacteriol 1997;47:1013-9.

[18] Wolin EA, Wolin MJ, Wolfe RS. Formation of methane by bacterial extracts. J Biol Chem 1963;238:2882-6.

[19] Hungate RE. A roll tube method for cultivation of strict anaerobes. Methods Microbiol 1969;3B:117-32.

[20] Doetsch RN. Determinative methods of light microscopy. In: Gerhardt P, editor. Manual of methods for general bacteriology. Washington, DC: American Society for Microbiology; 1981. p. 29-30.

[21] Winker S, Woese CR. A definition of the domains Archaea, Bacteria and Eucarya in terms of small subunit ribosomal RNA characteristics. Syst Appl Microbiol 1991;14:305-10.

[22] Thompson JD, Gibson TJ, Plewniak F, Jeanmougin F, Higgins DG. The CLUSTAL $X$ windows interface: flexible strategies for multiple sequence alignment aided by quality analysis tools. Nucleic Acids Res 1997;25:4876-82.

[23] Saitou N, Nei M. The neighbor-joining method: a new method for reconstructing phylogenetic trees. Mol Biol Evol 1987;4:406-25. 
[24] Kumar S, Tamura K, Nei M. MEGA3: integrated software for molecular evolutionary genetics analysis and sequence alignment. Brief Bioinform 2004;5:150-63.

[25] Felsenstein J. Confidence limits on phylogenies: an approach using the bootstrap. Evolution 1985;39:783-791.

[26] Esteghlalian A, Hashimoto AG, Fenske JJ, Penner MH. Modeling and optimization of the dilute-sulfuric-acid pretreatment of corn stover, poplar and switchgrass. Bioresour Technol 1997;59:129-136.

[27] Lloyd TA, Wyman CE. Combined sugar yields for dilute sulfuric acid pretreatment of corn stover followed by enzymatic hydrolysis of the remaining solids. Bioresour Technol 2005;96:1967-77.

[28] Liu H, Zhang T, Fang HHP. Thermophilic hydrogen production from a cellulose containing wastewater. Biotechnol Lett 2003;25:365-9.

[29] Shin HS, Youn JH, Kim SH. Hydrogen production from food waste in anaerobic mesophilic and thermophilic acidogenesis. Int J Hydrogen Energy 2004;29:1355-63.

[30] O-Thong S, Prasertsan P, Intrasungkha N, Dhamwichukorn S, Birkeland NK. Improvement of biohydrogen production and treatment efficiency on palm oil mill effluent with nutrient supplementation at thermophilic condition using an anaerobic sequencing batch reactor. Enzyme Microb Technol 2007;41:583-90.

[31] Ahn Y, Park EJ, Oh YK, Park S, Webster G, Weightman AJ. Biofilm microbial community of a thermophilic trickling biofilter used for continuous biohydrogen production. FEMS Microbiol Lett 2005;249:31-8.

[32] Shin HS, Youn JH. Conversion of food waste into hydrogen by thermophilic acidogenesis. Biodegradation 2005;16: 33-44.

[33] Ganghofer D, Kellermann J, Staudenbauer WL, Bronnenmeier K. Purification and properties of an amylopullulanase, a glucoamylase, and an alphaglucosidase in the amylolytic enzyme system of Thermoanaerobacterium thermosaccharolyticum. Biosci Biotechnol Biochem 1998;62:302-8.

[34] Hoster F, Daniel R, Gottschalk G. Isolation of a new Thermoanaerobacterium thermosaccharolyticum strain (FH1) producing a thermostable dextranase. J Gen Appl Microbiol 2001;47:187-92.

[35] O-Thong S, Prasertsan P, Karakashev D, Angelidaki I. Thermophilic fermentative hydrogen production by the newly isolated Thermoanaerobacterium thermosaccharolyticum PSU-2. Int J Hydrogen Energy 2008;33:1204-14. 